\title{
ELEMENTI IMPRESIONIZMA U MORU ĐURE SUDETE
}

\author{
Melanija Ivezić Talan - Dean Slavić
}

Sveučilište u Zagrebu

Filozofski fakultet

dean.slavic@gmail.com

mivezic@ffzg.hr

\author{
UDK: 821.163.42.09Sudeta, Đ.-32 \\ 7.036.2:82-32 \\ https://doi.org/10.34075/cs.55.1.6 \\ Pregledni znanstveni rad \\ Rad zaprimljen 5/2019.
}

\section{Sažetak}

Članak tumači impresionističke elemente u pripovijetci „Mor“ Đure Sudete pozivajući se poglavito na postavke o impresionizmu Viktora Žmegača, teorije lirskoga Emila Staigera ipercepcije zbilje Ernsta Macha. Autori proučavaju odnose ljudskoga tijela i prirode, probleme vremena $i$ subjekta te iznose modernističke elemente nestabilnosti subjekta $u$ obzoru glavnoga lika Mora, protagonistkinje Šu i njezina oca. Tekst također ukazuje na stilsku blizinu Sudetina Mora s drugim junacima iz modernističkoga razdoblja hrvatske književnosti, osobito Leskovarovih Marcela Bušinskoga i Đure Martića te Kozarčeva Đuke Begovića. likovi

Ključne riječi: Sudeta, Mor, impresionizam, subjekt, priroda,

\section{PROZA U IMPRESIONIZMU}

Lirski doživljaj svijeta u samoj je biti impresionističke stilske tendencije u umjetnosti s kraja devetnaestoga i početka dvadesetoga stoljeća. Na polju književnosti novi svjetopogled unio je znatne promjene u strukturu proznih djela. Roman ustupa mjesto kraćim proznim vrstama, poput crtice ili pripovijesti. ${ }^{1}$ Napušta se široki „panoramski pregled“ pojavne zbilje, a pozornost se usmjerava istraživanju ljudske duševnosti. Impresionistička pripovijest poprima oblik samoispovijesti kojoj je „prvenstveni zadatak da potresa

1 „... kratkoća pripada biti lirskoga.“, u: Emil Staiger, Temeljni pojmovi poetike, Ceres, Zagreb, 1996., 80. 
ljudsku dušu, uzbuđuje čuvstva, donosi nove podražaje i otvara nove vidike". ${ }^{2}$

Prozna djela približavaju se, sadržajno i oblikovno, izrazu lirske pjesme. Tako bilježimo slabljenje fabule i uzročno-posljedičnog slijeda događaja, fragmentarnu kompoziciju, prevagu opisa ugođaja nad radnjom, mnoštvo lirskih motivskih skupova te hipersenzibilnoga, dekadentnoga (,slaboga“) junaka ili antijunaka usmjerenog na vlastiti unutarnji svijet. ${ }^{3}$

Važno je naznačiti da je postupak defabularizacije proze započeo u svjetskoj književnosti 19. stoljeća ${ }^{4}$ dok ga se kao važnu modernističku tendenciju valja promatrati u okviru novih duhovnih strujanja svjetonazorskoga karaktera koja su ujedno dovela i do promjena u shvaćanju smisla i cilja književnosti. ${ }^{5}$ „U europskoj umjetnosti na prijelazu protekloga fin de sièclea artizam se pojavio u sklopu one pojave koju bismo mogli nazvati ontološkom krizom, tj. novim načinom u shvaćanju i oblikovanju zbilje. Na široj duhovnoj i kulturnoj razini ontološka je kriza bila posljedica sloma pozitivizma, a na području umjetnosti posljedica iscrpljivanja mimetičkoga načela u realističkoj poetici."6 Istodobno, dakle, sa smjenom pozitivističke filozofije novom idealističkom filozofijom, utilitaristička funkcija književnosti biva zamijenjena onom esteticističkom. Time i preslika, kao i spoznaja pojavne zbilje prestaje figurirati kao vrhovno načelo umjetnosti.

Hrvatska književnost prijeloma stoljeća u duhovnom je suglasju s europskom književnosti toga doba: zbog negativnog odnosa prema zbilji „umjetnost u doba moderne umjetnikova je subjektivna projekcija, ona je sublimacija i rekreacija zbilje“. ${ }^{7}$ Iako su hrvatski modernisti politički angažirani pojedinci (Domjanić, primjerice), kao umjetnici su eskapisti koji u umjetničkim djelima nalaze utočište pred zbiljom. U

2 Milivoj Dežman Ivanov tim će riječima opisati fenomen „nove“ umjetnosti. V. Miroslav Šicel, Povijest hrvatske književnosti. knj. 5. Književnost moderne, Liber, Mladost, Zagreb, 1978., 113.

3 Usp. Franjo Grčević, Simbolizam, ekologija, eshatologija, Matica hrvatska, Zagreb, 2002.

4 Turgenjev je, primjerice, u pripovijestima fabulu retardirao lirskim motivima.

5 Usp. Miroslav Šicel, Povijest hrvatske knjižeunosti. knj. 5. Knjižeunost moderne, Liber, Mladost, Zagreb, 1978., i Dubravka Oraić Tolić, Matoševa proza, u: Zoran Kravar, Lirika i proza Antuna Gustava Matoša, Školska knjiga, Zagreb, 1996.

6 Dubravka Oraić Tolić, Matoševa proza, u: Zoran Kravar, Lirika i proza Antuna Gustava Matoša, Školska knjiga, Zagreb, 1996., 54.

7 Isto. 
takvim, artificijelno stvorenim, „separeima“ ${ }^{8}$ ljepota zamjenjuje mimezu „na tronu“, dok se zbilji prilazi isključivo s estetskoga kriterija. Stoga je i krajolik jedini prostor pojavne zbilje koji zanima modernog umjetnika. ${ }^{9}$

\section{Elementi IMPRESIONIZMA U MORU}

\subsection{Ljudsko tijelo i priroda}

Đuro Sudeta vodio se u Moru afinitetom modernoga umjetnika. U toj hibridnoj pripovijesti prepoznajemo strukturne postupke karakteristične za impresionističko poetičko usmjerenje. Jedan od tih postupaka je i defabularizacija. Sama fabula pripovijetke je jednostavna: Mor, sin upravitelja vlastelinskog imanja, zaljubi se u Šu, kćer vlastelina. No stari vlastelin pronalazi kćeri drugog ženika, plemića Arna, kockara i pustolova - pravu suprotnost Moru. Arno uspijeva nagovoriti vlastelina na projekt eksploatacije šume, pa tako vlastelin otpušta staroga upravitelja te zajedno s Arnom i njegovim prijateljem, kartaškim ortakom, kreće u projekt. Stari upravitelj umire od tuge a Mor, izgubljen zbog neostvarene ljubavi, nestaje $u$ šumi i pretvara se $\mathrm{u}$ vukodlaka.

U pripovijetki je, međutim, zbivanje u drugom planu. Ono što preteže je ugođajni prikaz događaja. Hrvatska književna kritika (Donat, Petrač, Lončarević) složna je u ocjeni da je Sudeta u jednostavnoj pripovijesti o nesretnoj ljubavi satkao neobičan prikaz vlastitoga egzistencijalnoga stanja. U tome mu je krajolik poslužio kao savršena „utičnica“: Zrakje mirisao po zrelom grožđu. Jato ždralova prolazilo je u visinama. Nebo je postajalo sve čišće i prozirnije. Povjetarac poigravao u krošnjama. Jedna mu se grana uplela o prsa, pa drhti. Spušta se i diže u ritmu njegovih grudi. Lišće šuti i gine u tuzi. Iz doline dopire lavež pasa, alije i on samotan i otajan kao strah. I zvijezde se miču. ${ }^{10}$

Prema teoretičaru književnosti Emilu Staigeru, fundamentalni pojam ugođaja „ne znači zatjecanje neke duševne situacije. (...) Ugođaj iskonski zapravo nije nešto što bi opstojalo 'u' nama. Nego smo u ugođaju na neki izraziti način 'vani'; ne nasuprot stvarima

8 Termin Zorana Kravara. Usp. Zoran Kravar, Svjetonazorski separei. Antimodernističke tendencije u hrvatskoj književnosti ranoga 20. stoljeća, Golden marketing - Tehnička knjiga, Zagreb, 2005.

9 O odnosu moderne (i ostalih razdoblja hrvatske književnosti poslije moderne) prema zbilji v. u tipološkoj studiji Pavla Pavličića, Mala tipologija moderne hrvatske lirike, Matica hrvatska, Zagreb, 2008.

10 Đuro Sudeta, Mor, Školska knjiga, Zagreb, 2005., 49. 
nego $u$ njima i one $u$ nama. (...) Ima zato smisla reći da jezik govori koliko o ugođaju večeri toliko i o ugođaju duše. Oboje je nerazlučivo jedinstvo. Posve se tu potvrđuju Amielove riječi : 'Un paysage quelconque est un état de l'âme.' (Određeni je krajolik stanje duše.) Ne tiču se te riječi samo krajolika. Sve što bivstvuje dapače u ugođaju nije predmet nego stanje. Biti stanjem način je bitka čovjeka i svijeta u lirskoj poeziji."11 Pritom kao važan fenomen ili označnicu „za sve što ukida razmak između nas i vanjskoga svijeta“12 Staiger izdvaja tjelesnost: „Tjelesnošću se dakle ne ćutimo kao individualnost ili kao osoba ili jastvo određeno poviješću svoga života. Ćutimo krajolik, večer, milu dragu - ili, još točnije: u večeri i u dragoj ćutimo s e b e. Nestajemo u onome što ćutimo." 13

U Sudetinoj pripovijetki dimenzija tjelesnosti ili „tjelesnih čuvstava“ veoma je naglašena. Bilježimo je, prije svega, u odnosu Mora i Šu: Mor je drhtao. Ćutio je njezinu ruku u svojoj. Ona je podrhtavala. Kad god bi se toga sjetio, on bi sav uzdrhtao. (...) Mor se zagleda dugo u njezine oči. Grudi su mu se zatalasale kao more. Nikad joj oči ne bijahu tako sjajne i velike., Ćutio je njenu ruku u svojoj kosi - i bojao se da joj pogleda u oči i usta. Čini se da su one danas crvene kao koralj... i sjajne ko zvijezde na horizontu. (...) Grudi mu se nadimahu kao mijehovi puni vina i užitka... Gledao je u daljinu i slušao melodiju njena glasa kako leprša među borovima i osjećao da ga je nekad sanjao. (...) Mor gleda u njezine oči i zvijezde - i već ništa ne razlikuje. Čini mu se da je negdje daleko iza horizonta gdje tinjaju same zvijezde i gdje se nalazi kraj. Burkaju mu se grudi i kosa zagasita ko ponoć poigrava na vjetru., S tim mu je osjećajem i dala ruku koju on dršćući prihvati. Prolazili su prema dvorcu. Morova je zagasita kosa drhtala u zraku. ${ }^{14}$

Tjelesnost je važan faktor u karakterizaciji likova. Kontrasti u fizičkom oblikovanju Mora i Arna nose simboličko značenje. Tako se simbolom kose ističe Morova snaga i strast: Pljeskali su mi kad sam ronio. Divili se mojoj snazi., Krv mu jurne u glavu i kosa mu se stade rasipati kao strast., Mor, njegov sin, radi nekoliko koraka od njega. Crna mu se kosa razastire kao strast, a grudi škripe kod svakog pomicanja. Brekte mu žile - i mišice se nadižu kao živo sječeno gvožđe., Morova je zagasita kosa drhtala u zraku. ${ }^{15}$

11 Emil Staiger, Temeljni pojmovi poetike, Ceres, Zagreb, 1996., 62.

12 Isto, 67.

13 Isto.

14 Đuro Sudeta, Mor, Školska knjiga, Zagreb, 2005., 51, 52, 45.

15 Isto, 13, 28, 19, 45. 
Opis Mora priziva nazorovski „hiperbolični patos“. ${ }^{16}$ Kao što navodi Krešimir Nemec, u karakterizaciji Mora iščitava se elementarnost i životnost. ${ }^{17} \mathrm{U}$ prilog tome govori Morovo brončano lice, snaga i kosa: Njegove su crte grube, tučane, ni jedan pokret ne odaje ni sjenku sumnje da je nekad prolazio gradskim ulicama kao gimnazijalče., Zasrebri mu se grubo brončano lice $i$ kose se raspu kao strast. ${ }^{18}$ Arno, naprotiv, ima rijetku kosu i krhke je građe: Njegov je stas vitak, plemićki, a kosa mu je zagasita, rijetka. Pripovijedaju da je to znak velikog talenta. ${ }^{19}$

Vrijedi, osim toga, napomenuti kako se u karakterizaciji svih likova izdvajaju oči i prije svega glas. Kao svojevrsni „Znakovi“ identiteta u pripovijetki, pogled i glas imaju istu funkciju kao i priroda - oni odražavaju stanja likova: Moru zastade dah. Pogled mu se zamrači i zatetura..., Mor sluša svoj sopstveni glas. A on je pun straha i bojazni. Pun nekog dalekog očekivanja., Njegove oči gore, plamte, izgaraju. Njegov je glas u svim visinama i dubinama; on se mijenja, titra, poigrava kao harfa na povjetarcu jesenjem. Gori, bukti i jeca. Kida se iz duše i žali, pritajiva se i razgaljuje do najtiših dubina., A kad je Mor na rastanku podigao svoje oči do njezinih, zaboravioje na sve što ga je još sinoć tako vrijedalo i boljelo. One su bile iste, nepomućene i odane - baš kao i lani., Mor je htio odgovoriti starom vlastelinu, ali ga pogled ušutkao., Mor se prenu. Gledao juje pogledom koji je molio i kleo, plakao i prkosio., Seljaci su stajali u aleji i razgovarali. Glasovi su im bili zabrinuti i polomljeni. Jedan je pitao pogledom drugoga, kao da bi htio otkriti u njemu ono što mu samom nije uspjelo., Upravitelj se zapanjio... Vidjelo se daje vrlo uzbuđen... Spustio se ponouno na krevet. Glas mu je bio plah., Ljudi su govorili i tužili se. Načas bi umuknuli, pa bi se opet javili. A svakije glas bio prebit kao duša iz koje je potjecao. ${ }^{20}$

Znakovito je, primjerice, kako Mor na kraju pripovijetke gubi sposobnost govora.

U fizičkoj karakterizaciji Mora i Šu važan čimbenik predstavlja i priroda: Moja su prsa rutava, zamršena, divlja; moje su oči sive, modre, plave; one su prozirne kao maslačak kad dođe jesen; kao zim-

16 I pjeva: 'Ja sam danas ispio sunce plamno. / I žilice su moje nabrekle ko potoci. / U utrobi se mojoj ljuljuška more tamno. / Na leđima mi šuma, što nagli trgnu srh. / Dv'je st'jene, dva obronka postaše moji boci, / a glava-gorski vrh. Preuzeto iz: Krešimir Bagić, Rječnik stilskih figura, Školska knjiga, Zagreb, 2012., 141.

17 Đuro Sudeta, Izbor iz djela, priredio Krešimir Nemec, Riječ, Vinkovci, 2000., 10.

18 Đuro Sudeta, Mor, Školska knjiga, Zagreb, 2005., 19, 54.

19 Isto, 13.

20 Isto, 38, 21, 48, 29, 28, 44, 68, 48, 67. 
zelen kad dođe proljeće; one su kao šuma u kojoj živim., Zar su to oni osjećaji koji je znadu probuditi u noćima kad se proljeće rađa iza proplanaka? Kad joj se prisni čupava, brončana glava i usne kao koralj crvene $i$ žedne, rastvarajući se ko rumene latice ruža u zoru., Njezine su oči velike, začuđene, okupane i suježe kao zvijezde na širokom nebu., Šu prelazi brzo rukom preko čela. Oči joj postaju velike i otajne $i$ usne crvene kao šipak., Šu zaklopi oči kao dva topla potočna cvijeta... ${ }^{21}$

Motivski i ritmički sloj opisa slijedi biblijski predložak - Pjesmu nad pjesmama: Kako si lijepa, prijateljice moja, / kako si lijepa! / Imaš oči kao golubica / (kad gledaš) ispod koprene. / Kosa ti je kao stado koza / što izađoše na brdo Gilead. / Zubi su ti kao stado ovaca / ostriženih / kad s kupanja dolaze:/ idu dvije i dvije kao blizanke / i nijedna nije osamljena. / Usne su tvoje kao trake od grimiza / i riječi su tvoje dražesne, / kao kriške mogranja tvoji su obrazi / pod koprenom tvojom. ${ }^{22}$

U prirodi, osim toga, nestaje razmak između likova i vanjskog svijeta. Priroda je onaj element koji „stvara“ ugođaj: Malo poslije ručka izašao je upravitelj na livade, a Mor je legao pod divlji jorgovan koji se upravo rascujetavao poslije zadnje kiše. Taj ga je miris tako opajao, da se osjećao mnogo lakšim i suježijim. ${ }^{23}$

S pozicija impresionizma ugođaj (njem. 'Stimmung') riječ je koja se najčešće ponavlja: „Bit je ugođaja da utjecaj osjetilnih čimbenika $\mathrm{u}$ danome trenutku postaje premoćan pa dolazi do stapanja sredine (krajolika, okruženja uopće) i ljudskoga senzorija odnosno trenutnoga raspoloženja. Takvo je 'utapanje' psihe u nekom ambijentu neobično znakovito za impresionističku senzibilnost (...).“24

\subsection{Impresionizam, Mor i vrijeme}

Ovdje se valja nadovezati na filozofsku podlogu impresionizma u kojoj se posebno izdvaja misao Ernsta Macha i njegova teorija osjetilnosti prema kojoj se zbilja percipira ponajprije osjetilima. ${ }^{25}$ Kako objašnjava Mach, u naravi je osjetilnih kompleksa/sklopova (akustičkih, vizualnih, taktilnih i drugih) stalna mijena pa stoga i

\footnotetext{
Isto, 16, 34, 15, 50, 85 .

22 Pjesma nad pjesmama, 4, 1-3.

23 Đuro Sudeta, Mor, Školska knjiga, Zagreb, 2005., 25.

24 Viktor Žmegač, Duh impresionizma i secesije, Zavod za znanost o književnosti Filozofskoga fakulteta Sveučilišta u Zagrebu, Zagreb, 1993., 37.

25 Mach će tako i kategorije prostora i vremena „podvesti” pod osjete. Usp. Viktor Žmegač, Duh impresionizma i secesije, Zavod za znanost o književnosti Filozofskoga fakulteta Sveučilišta u Zagrebu, Zagreb, 1993., 17.
} 
„ne postoji drugi identitet osim trenutnoga“, ${ }^{26}$ ukoliko se uopće može govoriti o identitetu. Tako su česti motivi impresionizma odrazi u vodi, zrcaljenja, koloristička nijansiranja, sjene te ostale nestalne, prolazne pojave kojima umjetnici nastoje "dati auru neizbrisivosti“ ${ }^{27}$ Ipak, „svijet u impresionista (...) ne poznaje istinsku dinamiku. Stoga je, ne samo u slikarstvu nego i u književnosti, jedno od osnovnih obilježja impresionizma sklonost prema statičkim prizorima ili prema situacijama u kojima subjekt nastupa samo kao promatrač“. ${ }^{28}$ U prikazu „uhvaćenog trenutka“ nema sukcesivnosti zbivanja, kategorija vremena gotovo da ne postoji. Zorno je to opisao Ivo Frangeš analizirajući Matošev sonet Jesenje veče: „To je neka vrsta stajaće, ukočene vječnosti." 29

Već prva rečenica Sudetine pripovijetke upućuje na autorovu naklonjenost prezentu: Kad počne stizavati mračak za mračkom $i$ bude ih puna soba $i$ dvor i podvornica - sve do ribnjaka na kraju šume, dolazi mi obično ona i otvori prozor!... ${ }^{30} \mathrm{U}$ Moru je, osim toga, na djelu „produženo“ vremensko trajanje : Čulo se kako teče Pločnica i cuijeće niče ispod lišća., Drvo se giba, čuje se kako korijen prelazi preko korijena i duhovi mrtvih lugara šušte u krošnjama., Zagledam se dugo, dugo tamo nekuda, tako dugo, dok se ne ražalostim i budem beskrajno nujan i samotan., Mor upaljuje petrolejku i sjeda. Sluša kako dolazi noć i kako prolazi vrijeme. Tiho, tiho kao tuga., Ona se lagano spušta kroz sumrak. Nestaje. Ode., Dan je prolazio preko šume. Žurio se. Imao je krila i letio je ko jato grlica. Lepet njegovih krila ostavljao je nepoznat miris iza sebe, a ovaj izmicao iza gora. ${ }^{31}$

Stječe se dojam „zaustavljenog vremena“. Naime, opetovanim „umiranjem dana“, prolaskom voda i oblaka „sve je položeno u istu

$26 \quad$ Isto, 25.

27 Viktor Žmegač, Impresionizam, u: Hrvatska književna enciklopedija, T. 2., Leksikografski zavod Miroslav Krleža, Zagreb, 2010., 146.

Usp.: „... jer život sačinjava samo onaj sekund vremena, kad ga realno proživljujemo, dakle: baš onaj sekund, kad smo u njemu. Već drugi minut on je za nas ništa - vriedi onaj drugi... i tako redom...", u: Đuro Sudeta, Proza. II. (Tuga, Feljtoni, Humoreske, Intimni Sudeta), Izdanje hrvatskog izdavalačkog bibliografskog zavoda, Zagreb, 1943., 228, 230.

28 Viktor Žmegač, Duh impresionizma i secesije, Zavod za znanost o književnosti Filozofskoga fakulteta Sveučilišta u Zagrebu, Zagreb, 1993., 37.

29 Isto, 67.

30 Đuro Sudeta, Mor, Školska knjiga, Zagreb, 2005., 9.

31 Isto, 55, 62, 9, 43, 46, 47.

U tom smislu zanimljiva je i uporaba prijedloga kroz i preko u posljednja dva citata. 
vremensku ravninu“. ${ }^{32}$ U svom trajanju izjednačuju se dani, godine i vjekovi: Prolaze vode, oblaci prolaze i dani ispod njih prolaze. Dolaze - prolaze. Provuku se plave sutonove sjenke, prokaplju mračci kroz prozore, provuku se, pritaje, pa ih nestane. Nestane sunca, boja nestane $i$ dan se za danom ugasi i ode nekuda u daljine. Tamo su već prošli vjekovi, život i godine. ${ }^{33}$

Ovdje je zapravo riječ o „ugođaju koji ukida vrijeme“34: Dan se gasi. Umire po bojama stakala i lišća. S majura plove magle i zvona $i$ razliježu se u šumi... Tako prolazi dan. Tako će proći i noć..., Prolazi podne, prolazi popodne. Dolazi sumrak., Završuje dan. Sasvim sličan onome koji je juče umro. (...) Glas umre u tišini. ${ }^{35}$

Impresionistički doživljaj života podrazumijeva i sljedeće: „najsretniji su životni trenuci kada zaboravljamo granice svog individualiteta i uranjamo u osjećajni sklad s prirodom ili drugim bićima te kada smo u sjećanjima ili sanjarijama 'izvan' takozvane svakodnevne svijesti."36 Važno je opaziti kako i Staiger razvija misao o lirskom „međuprožimanju“: „Lirski je pjesnik (...) mek, to znači da obrisi jastva, vlastita opstanka, nisu čvrsti (...) Tko voli, 'zadubljuje se' - koje li riječi! - u lice drage. (...) pa je onda i lirski pjesnik doi-

32 Frangešov opis Matoševa soneta. Preuzeto iz: Viktor Žmegač, Duh impresionizma i secesije, Zavod za znanost o književnosti Filozofskoga fakulteta Sveučilišta u Zagrebu, Zagreb, 1993., 67.

33 Đuro Sudeta, Mor, Školska knjiga, Zagreb, 2005., 19.

34 Viktor Žmegač, Duh impresionizma i secesije, Zavod za znanost o književnosti Filozofskoga fakulteta Sveučilišta u Zagrebu, Zagreb, 1993., 70.

35 Đuro Sudeta, Mor, Školska knjiga, Zagreb, 2005., 32, 41, 43.

36 Misli Ernsta Macha. Preuzeto iz: Viktor Žmegač, Duh impresionizma i secesije, Zavod za znanost o književnosti Filozofskoga fakulteta Sveučilišta u Zagrebu, Zagreb, 1993., 23.

Usp.: „Kad se bližila večer, spuštao sam se s vrhova otoka i rado sam sjedao uz obale jezera, na žal, na neko skrovito mjesto; tamo su šum valova i uzburkanost jezerskih voda, smirujući moja osjetila i tjerajući iz moje duše svaku drugu uzburkanost, uranjali moju dušu u divno sanjarenje u kojemu bi me često znala zateći noć a da to ne bih ni primijetio. Nadolaženje i povlačenje vode, njezin neprekidan ali na mahove pojačan šum, koji su neprestano dopirali do mojih očiju i ušiju, nadomještali su unutarnje uzbuđenje koje je sanjarenje stišavalo u meni i bili su dostatni da s užitkom osjećam svoje postojanje, ne trudeći se da mislim. S vremena na vrijeme rađala bi se u meni neka slabašna i kratkotrajna misao o nestalnosti zemaljskih stvari, čiju mi je sliku pružala površina vode, ali uskoro bi se nestalni dojmovi gubili u jednoličnosti neprekidnog gibanja koje me uljuljkivalo i koje me bez ikakva aktivnog sudjelovanja moje duše ipak toliko vezivalo da se, kad bi me upozorilo vrijeme i dogovoreni znak, nisam mogao otrgnuti odatle bez napora.", u: Jean-Jacques Rousseau, Sanjarije samotnog šetača, Matica hrvatska, 1997., 62-63. 
sta najneslobodniji, predao se posvema, izvan sebe je, nose ga vali čuvstva." 37

Označnice lirskoga stila u Moru moguće je, stoga, „katalogizirati“ i kao signale književnog impresionizma. Riječ je o fenomenima prolaznosti/nestalnosti/fluidnosti, prožimanja, sjećanja, prvenstvu osjećaja i ugođaja nad radnjom te jedinstvu zvuka i značenja riječi. Cilj je impresionističke mimeze, naime, dočarati mnoštvo nijansi u prirodnim pojavama. U tome je jezik od presudne važnosti. Sudetinu naklonjenost neposrednom doživljaju prirode, kao i osjećaj za nijansu u jeziku, valja označiti impresionističkim elementima, i to $\mathrm{u}$ onom segmentu gdje se zbilja, odnosno priroda, doživljava osjetilima njuha, oka, sluha, dodira: Iz šume dolaze mirisi jagoda i ljetna tišina., Čujem: kako plaču zeleni valovi stare Pločnice, što teku kroz vlaće trava; osjećam miris jetrenke, šumskih gljiva i jaja. Zagledam se dugo, dugo tamo nekuda, tako dugo, dok se ne ražalostim $i$ budem beskrajno nujan i samotan., Zvijezde su tinjale na horizontu, ali se nisu vidjele. Krošnje. Potitravanje krošnja oduljivalo se u visine i beskraje. Za brdima je disala noć suježa i vitka kao jelenče, ali je Mor nije osjećao. ${ }^{38}$

Priroda je, međutim, „u skladu s impresionističkom senzibilnošću“,"39 internalizirana, odnosno „prerađena“ osjećajima. Oblikovanju prostora šume Sudeta pristupa afektivno, nastojeći „i na čitatelja prenijeti svoj 'osjećaj života'“. ${ }^{40}$ Poput Matoševa Hrvatskoga zagorja ${ }^{41}$, Sudetina šuma „nije empirijski dostupna predmetna zbilja koja se dade prikazati u mimetičnim opisima. To je subjektivna estetska konstrukcija, imaginarni prostor duše, koji autorski lik ispunjava svojim neposrednim dojmovima (...)“42: Mor izađe iz kuće, udahne svježinu šume i zapjeva nešto preko volje. Silio se sam da bude što bolje volje. Prolazeći mimo jednog brijesta, popne se na nj i izvadi male kune koje su imale u njemu gnijezdo. Obrao je nekoliko dozrelih kupinica i stao da ih kljuka. Životinjice se neprestano branile, a on se smijao i uživao. Mali im zubići postadoše crni, kao da su bili u dimnjaku. Pčele su na proplanku zujale i letjele bez ika-

37 Emil Staiger, Temeljni pojmovi poetike, Ceres, Zagreb, 1996., 69-70.

38 Đuro Sudeta, Mor, Školska knjiga, Zagreb, 2005., 13, 9, 61.

39 Viktor Žmegač, Duh impresionizma i secesije, Zavod za znanost o književnosti Filozofskoga fakulteta Sveučilišta u Zagrebu, Zagreb, 1993., 88.

40 Krešimir Nemec, Lirski roman Ive Kozačanina, u: Tragom tradicije, Matica hrvatska, Zagreb, 1995., 110.

41 Ovdje se misli na Matošev glasoviti putopis "Oko Lobora”.

42 Dubravka Oraić Tolić, Matoševa proza, u: Zoran Kravar, Lirika i proza Antuna Gustava Matoša, Školska knjiga, Zagreb, 1996., 117. 
kva znaka da će se rojiti. No Mor i nije drugo očekivao. Legao je na mahovinu pod brijestom $i$ stao da ih promatra. Šumorenje sunca nad krošnjama i zujanje pčela vrh njih nabrzo ga uspava. Pčele su zujale, premetale se u sunčanoj prašini, a gdjekoja bi se spustila i na njegova rutava prsa. Sunce se nagibalo u kosom putu, sve više prosipajući se u žutozlatnim kolutovima. ${ }^{43}$

\subsection{Problemi subjekta}

S obzirom da se Machova koncepcija trenutnoga identiteta zbilje „preslikava“ i na poimanje subjekta, „kategorija nazvana 'ja' nije nimalo postojanija negoli druga tijela". ${ }^{44}$ Subjekt se, naime, određuje kao „sprega (kompleks) sjećanja, ugođaja i osjećaja“. ${ }^{45}$ Ipak, filozof u fenomenu sjećanja „vidi šav“ koji spaja „bivše“ i „sadašnje“ ja: „(...) Mach je teoretičar impresionizma, protiv svoje volje dakako, pogotovo ondje gdje razmišlja o značenju što ga za duševni život ima sposobnost ljudske svijesti da iz zalihe sjećanja na trenutke oživi pojedine slike iz prošlosti, dakle da davnu, zabilježenu, 'konzerviranu' osjetilnu prošlost prenese u sadašnji tren - često na temelju asocijacije izazvane novim, trenutno aktualnim osjetom, a ta okolnost samo potvrđuje prodornu snagu osjetilnosti, koja premošćuje vrijeme i prostor." 46

Tragove „poetike sjećanja“ bilježimo i u Sudetinom Moru. Neizostavna priroda ovdje je u funkciji „spremnika sjećanja“, a ujedno se brišu razlike između subjekta i prirode, ovdje poglavito izraženo u grani jorgovana: A oblaci idu i teku preko šume kao velike bijele ptice. I oni me sjećaju! Sjećaju me da se budim i da živim; da živim i osjećam da ja nisam Mor s crnom kosom i rutavim prsima - da sam samo grana jorgovana - samo grana jorgovana., Kad u jesenska predvečerja utonu oblaci iza brda - i zvijezde zaplaču na pustom tajanstvenom obzoru, on pridigne oči $i$ tad se sjeti Nje..., Samo katkad, ali to je tako rijetko, sjeti se on da je bio nekad čovjek - i onda se prikrade kroz šibike i ševare na kraj šume - $i$ u predvečerje kad tonu zvijezde za oblacima iza horizonta - sjedne na panj na rubu šume i gleda na cestu - $i$ put, kao da čeka nekoga da mu se vrati! Tko će se to nje-

43 Đuro Sudeta, Mor, Školska knjiga, Zagreb, 2005., 26.

44 Viktor Žmegač, Duh impresionizma i secesije, Zavod za znanost o književnosti Filozofskoga fakulteta Sveučilišta u Zagrebu, Zagreb, 1993., 18.

45 Isto.

46 Isto, 25. Ovi redci podsjećaju na fenomen kolačića madelaine Marcela Prousta. "Skrovitu srodnost" Prousta i Macha uočava i Viktor Žmegač u svojoj studiji. Podsjećaju također i na Galovićev ciklus pjesama $Z$ mojih bregov. 
mu vratiti!?... Biva to samo onda kad pupaju šume i vrući se vjetrovi prosiplju s južnih proplanaka - i opet kad zažute i zašume vjetrovi i lišće se stane spuštati s brda i dolina zasipajući putove i prosjeke! Svakog proljeća $i$ svake jeseni. ${ }^{47}$

Sudetinog junaka razložno je označiti machovskim subjektom. Naime, osim sjećanja i ugođaja njegov svijet određuju i osjećaji: Ljubim vas, Šu, ljubim. Toje sve što znam. Sve. Ja ne znam je li dobro, pametno, je li to logično i slobodno, da li je taj osjećaj u meni ili izvan mene. Sve ja to ne znam. Šu, ja sam tek prost čovjek, a vašje otac plemić i ja sam njegov i vaš podanik. Ali srce za to ne pita. To je za njega nuzgredno. U večeri sumorne kradem vam se pod prozore, bacim vam bokor šumskih ruža u sobu i pobjegnem, da me ne bi ukorili. Ja sam boem!, A zašto ja to osjećam? Osjećam intuitivno neki strah., Htio je poći da nađe mjesto gdje bi oca spremio za neko vrijeme, ali ga nešto pridržavalo. Neki ludi osjećaj. Da ostane uz oca. Da ga ne ostavlja., Otac je šutio... Pružio je ruku (Mor ju je ćutio u mraku) ogrlio ga - izljubio - i pružio se na krevet... Mor prestrašen $i$ zbunjen otrči po petrolejku, upali je i prinese nad krevet. Otac je već bio mrtav... ${ }^{48}$

Poetika Đure Sudete u cijelosti je obilježena subjektima s proširenim dimenzijama jastva, odnosno jastva koje ukljanja granice između sebe i objekata oko sebe. Razmišljanja glavnog lika Sudetine novele Rađanje čovjeka $\mathrm{u}$ tom su smislu posve u duhu teorije impresionizma: Možda je sve to u meni. I ova dolinica i zričci $i$ trave $i$ zvonovi i frule i hrašće ovito zimzelenom. Možda. Ali znam, da je liepo u meni. I da je to sve refleks moje unutrašnjosti. A ja sam dosad uviek tražio sve izvan sebe. U prostoru izvana. Išao sam u svemir $u$ daljine i prozračne dubine i bezdna. Lutao sam svuda. Potucao se po zviezdama i oblacima. Potucao? Ne! Ja to i danas tek naslućujem. Nisam ja išao ni $u$ svemir ni $u$ daljine ni $u$ oblake - nego $u$ sebe, $u$ svoju dušu. Nisam odkrivao ništa izvan sebe, ni mora ni planete: sve je to moralo biti u meni. ${ }^{49}$

Sudetine „daljine i prozračne dubine i bezdna“ moguće je dovesti u vezu s machovski intoniranom misli Milivoja Dežman Ivanova o nespoznatljivosti ljudske duše: „A ja i opet velim, nemojte misliti, da ste ikad ikoga spoznali, sebe samoga ponajmanje. Vidite, ja pomi-

\footnotetext{
47 Đuro Sudeta, Mor, Školska knjiga, Zagreb, 2005., 18, 92-93, 90.

48 Isto, 34, 13, 47, 55.

49 Đuro Sudeta, Proza. I. (Priče i novele), Izdanje hrvatskog izdavalačkog bibliografskog zavoda, Zagreb, 1943., 227-228.
} 
šljam pojedinca kao neki mozaik, kao skup milijuna najrazličitijih elemenata, a nipošto kao homogenu cjelinu. "50

Odjeke takvoga razmišljanja bilježimo i u Moru. Problem identiteta u središtu je ove pripovijetke: Lutam po neprohodima, spotičem se o klade. Mirisi igraju ovršjem drveća, a ja nutrinom svoje vlastite spoznaje. ${ }^{51} \mathrm{U}$ tom smislu osobito je važan kraj uvodnog poglavlja „Grana jorgovana“: Ja nisam Mor! Ja bih. Ja bih, možda, htio biti Mor - ali to nisam! A vi mislite da sam to ja. Vi mislite da sam ja Mor. Da vam ja to pričam... Ne! (Ali to i nije važno!) Ja sam, samo, grana jorgovana pokraj Morove kućice - kolibice! A meni se često pričini da samja-Mor i da imam ljudsko srce. (...) I ja tada pričam, kao da sam ja Mor, i da volim vlastelinovu kćerku. Da hodam po šumi i da imam isječena brončana lica i kose zagasite kao ponoć. Čini mi se da se verem gudurama iza horizonta u oblacima. Čini mi se da sam malo čovjek, malo cvijet, malo vuk s južnih proplanaka. Od svega ponešto. ${ }^{52}$

$\mathrm{S}$ istoga je stajališta zanimljiva mijena, ali i nestabilnost, $\mathrm{u}$ duševnim doživljajima glavnoga lika: Mor zatvara oči. Da ne gleda. Bolje je da ne gleda, da se pretvori u jednu granu ovog debla. Ili bar u jedan list. Onaj koji se sad otkinuo i pao na pijesak kraj klupe., $\mathrm{Na}$ vrhu brda nađe prvi panj; sunce se tek pomaljalo na istoku i grane su visjele kao grozdovi puni rose. Sjeo je na njega i prepustio se osjećaju koji ga je sve više obuzimao. I juče je sjedio tu. Na istom panju, a s koliko drugih osjećaja! Oni su se tako izmijenili kroz jednu noć, da ih više nitko ne bi mogao zajedno postaviti, ni on sam!, Počinjem sumnjati i smijati se onom što mi je prije bilo najveća, najmilija svetinja. Svejedno mi je kojim smjerom idu grane, kojim sjene njihove. Hodam $i$ hodim bez osjećaja; to je sue što znam! ${ }^{53}$

Navedeni redci prizivaju Machovu koncepciju identiteta: „U prilog svojoj tezi da je identitet stvari puka konstrukcija Mach ističe i nestalnost i varijabilnost ljudske ličnosti. Kao što se tijelo stalno obnavlja ali i mijenja, tako je i duševni život svakoga pojedinca stalno izložen dugoročnim i kratkoročnim mijenama: novim, ponekad fundamentalnim iskustvima, promjenama općih nazora, a isto tako, u kratkim razdobljima, čovjek je podložan raspoloženjima, sumnjama, duševnim šokovima. "54

50 Viktor Žmegač, Duh impresionizma i secesije, Zavod za znanost o književnosti Filozofskoga fakulteta Sveučilišta u Zagrebu, Zagreb, 1993., 29.

51 Đuro Sudeta, Mor, Školska knjiga, Zagreb, 2005., 16.

52 Isto, 18.

53 Isto, 49, 23, 15-16.

54 Viktor Žmegač, Duh impresionizma i secesije, Zavod za znanost o književnosti Filozofskoga fakulteta Sveučilišta u Zagrebu, Zagreb, 1993., 87. 
U skladu s time, u Moru prepoznajemo impresionističko nagnuće bilježenja protoka svijesti: Ležao sam još neko vrijeme $i$ slušao, a onda sam htio da odem. Ja sam to htio. I pošao sam. Ustao sam. Ustao sam i opet sam stao! Nisam znao što bih!?..., Bože moj! Znaš li možda ti zašto nisam juče pjevao kad je ona došla da sluša? Zašto baš juče? Idem, slušam, stanem, spotaknem se. Pa opet pođem, opet slušam i opet se spotaknem....5

\subsection{Mor kao modernistički lik}

Sudetin junak, osim toga, nosi prepoznatljive crte modernog lika ${ }^{56}$ : hipersenzibilnost, sjetu, nedostatak volje, prepuštenost sudbini, eskapizam: Mor sjedi i prisluškuje melodiju očeva glasa kako tone u sumraku. Sluša. Misli mu se bave brigama kako će $i$ što će učiniti. Osjeća da mu nedostaje jaka volja. A to ga ozlojeđuje. Tjera ga u očaj., Jedno su vrijeme ćutali. Mor je postajao sve nestrpljiviji. Nije mogao dočekati kad će otac početi. A nije imao snage da ga prvi pita., Mor se okreće i polazi u dolinu k bolesnom ocu - i osjeća da mu je u duši sve ono što je i prije bilo. Zašto joj nije to sve rekao? Zašto je tako slab?, U njemu se rađalo neko neodređeno čuvstvo. Neka tiha rezignacija i ravnodušnost. Sav onaj nekadašnji ljubomor koji ga je razdirao i mučio po danu i po noći, rasplinuo se poslije onog događaja u šumi u ništa. Prepustio je sve sudbini. Kad je znao da Šu dolazi na Pločnicu ili u šumu po jagode, uvijek joj se uklonio. Otišao bi kamo na livade, samo da se ne mora s njom sastati. ${ }^{57}$

Mora zaokupljaju zle slutnje na koje se nadovezuju osjećaji straha i nemoći: Ja vjerujem da ima nešto zlo što nas prati na svakom koraku. Koje hoće: da bude sve drukčije i obratno nego mi to želimo. Bojim ga se i bježim... Ko zvijer pred lovcima., Nešto ga goni da ode u kolibu po dvojnice. Da zasvira. ${ }^{58}$

Na nejasne slutnje junaka nailazimo i u prozi Vladimira Nazora: Ima nešto čega se ne mogu lišiti. Jest neki talog, mutan i muljav, na dnu moje biti. Jest neka golema, sluzava, a jaka ruka, koja me drži

\footnotetext{
55 Đuro Sudeta, Mor, Školska knjiga, Zagreb, 2005., 10, 17.

56 „Likove koji su utjelovljenje čvrstoće i volje potiskuju likovi u kojima se očituje pasivna senzibilnost.", u: Viktor Žmegač, Duh impresionizma i secesije, Zavod za znanost o književnosti Filozofskoga fakulteta Sveučilišta u Zagrebu, Zagreb, 1993., 42.

57 Đuro Sudeta, Mor, Školska knjiga, Zagreb, 2005., 42-43, 22, 46, 29.

58 Isto, 14, 54.
} 
u svojoj šaci. Jest nešto, što bih morao stresti iz sebe... ${ }^{59}$ Razvidna je poveznica između Nazorova i Sudetina lika: zajednička im je, naime, ideja „o nekakvom nedohvatnom i nespoznatljivom 'nešto' koje vlada ljudskim sudbinama (...)“. ${ }^{60}$ Štoviše, u liku Mora zamjetan je i vitalizam svojstven Nazorovoj poeziji i prozi te Matoševoj novelistici.

Prikazane karakterne crte Sudetina junaka idu u prilog postavci o Moru kao tipičnom modernom liku. U svojoj podvojenosti Mor je blizak i Kozarčevu Đuki Begoviću, koji se „uklapa u glavne preokupacije hrvatske moderne. U izgradnji njegova karaktera Kozarac je intuitivno objedinio divergentne sile razdoblja: sile dekadencije, pasivnosti, neurotičnosti i malodušnosti, koju oprimjeruju Leskovarovi antijunaci (Đuro Martić, Marcel Bušinski), ali i vitalne sile energije, snage i obnove, koje afirmira Nazor u svojim pjesmama, epovima i pričama. No naši literarni dekadenti nisu izrasli iz konkretne sredine nego su literarne tvorevine, kabinetski konstrukti: oni su tek modernizirane varijante 'suvišnih ljudi' iz ruskih romana 19. stoljeća“. 61

U slučaju Mora, međutim, riječ je o nadgradnji dekadentnog lika, ili o svojevrsnom „spoju“ literarne tradicije i zavičajnih elemenata, kao što je to, primjerice, legenda o vukodlaku: „Mor je uzet iz naroda. Kod mene govore vukodlaku - 'mor'!, Da sam baš uzeo 'Mor' za obradbu, potaknulo me i tebi poznato pričanje naše majke o 'vukodlaku'. Toliko o genezi same pričice."62

Vrijedi istaknuti kako začetke paradigme modernog junaka $\mathrm{u}$ hrvatskoj književnosti nalazimo u prozi Janka Leskovara: „Znatno prije Nehajevljeva Đure Andrijaševića iz romana Bijeg (1909), Leskovarov antijunak već posjeduje sve crte moderne duševnosti. Ta profinjena, osjetljiva i kontemplativna duša suptilno reagira na sve titraje i nijanse novoga doba. Svjesno ili nesvjesno, posredno (čitanjem) ili neposredno (na temelju vlastita iskustva), Leskovar je anticipirao bitne preokupacije književnosti hrvatske moderne."63

Sudeta je bio upoznat s Leskovarovom prozom. U pismu datiranom 4. ožujka 1922., svoje zdravstveno stanje opisuje prizivanjem

59 Riječ je o noveli „Nero“ iz ciklusa S planine. V. u: Vladimir Nazor, Izbor proze, I., Matica hrvatska, Zagreb, 1999., 390.

60 Miroslav Šicel, Povijest hrvatske književnosti, knj. 5. Književnost moderne, Liber, Mladost, Zagreb, 1978., 162.

61 Krešimir Nemec, Još o Đuki Begoviću, Nova Croatica, VI (2012.) 6, 292.

62 Đuro Sudeta, Proza. II. (Tuga, Feljtoni, Humoreske, Intimni Sudeta), Izdanje hrvatskog izdavalačkog bibliografskog zavoda, Zagreb, 1943., 283., 264.

63 Krešimir Nemec, Leskovarov antijunak ili literarni portret jednog dekadenta, u: Tragom tradicije, Matica hrvatska, Zagreb, 1995., 78. 
Leskovarove pripovijetke Katastofa u kojoj glavni lik Fran Ljubić boluje od tuberkuloze: „Sutra idem na kliniku. Katastrofa J. Leskovara. Blutsturz. I još štošta, što ni ja sam ne znam. Tamo ću valjda odležati mjesec dana. Tko mi je kriv? Ja? Ili tko drugi? - ili je tako moralo biti?" 64

Ljubića i Mora povezuje „ključna komponenta u tumačenju dekadentnog lika“. ${ }^{65}$ Riječ je o kategoriji volje. ${ }^{66}$ Dekadentni junaci, naime, mahom misle, ali ne djeluju, karakterizira ih „slaba“ volja, nemoć te bijeg pred stvarnosti: „Oni naznačuju onaj ključni zaokret koji donosi literatura fin de sièclea: mikrokozmizaciju problematike, internalizaciju (tj. "pogled iznutra') (...).“67 Prepoznatljivo obilježje Leskovarove proze psihološka je karakterizacija likova. „Leskovarce“ opterećuje (i pasivizira) „težak uteg“ prošlosti ili vlastita podvojenost (Marcel Bušinski iz Sjena ljubavi).

Sudetin „zaokret“ od tradicionalne proze ponajprije je posljedica naglašenog lirskog osjećanja svijeta. Tragika njegova junaka leži $\mathrm{u}$ neostvarenoj ljubavi. Neizbježivost krute realnosti ${ }^{68}$ u Moru rađa nemoć: Zar bi on imao snage da zaprosi u vlastelina ruku njegove kćerke? Možda bi to vlastelin i shvatio, jer i njemu nije ostalo sve prikrito i znao je dobro da Šu voli njega, ali zar bi bilo čudo kad bi se on na sve to našao nevješt $i$ preporučio mu liječnika za živčane bolesti. Jer je drugo srce, a drugo je logika života koja se javlja tek onda kad je ljubav mrtva. ${ }^{69}$

\section{5. Šu kao modernistički lik}

Šu je također pasivan lik, žrtva je autoritarnog odgoja, nespremna suočiti se s problemom: On je osjećao da ona trpi, ali mu to radi odgoja nije mogla predbaciti, nije imala toliko snage da se odupre nje-

64 Đuro Sudeta, Proza. II. (Tuga, Feljtoni, Humoreske, Intimni Sudeta), Izdanje hrvatskog izdavalačkog bibliografskog zavoda, Zagreb, 1943., 156.

65 Krešimir Nemec, Leskovarov antijunak ili literarni portret jednog dekadenta, u: Tragom tradicije, Matica hrvatska, Zagreb, 1995., 79.

66 „Zato je i Schopenhauer, taj filozof volje, mislilac koji je najjače utjecao na dekadentnu umjetnost kraja stoljeća.“, Isto.

67 Isto, 77.

68 Đuro Sudeta, Mor, Školska knjiga, Zagreb, 2005., 23. Ovdje se misli na socijalne/ staleške razlike.

U noveli „Tuga“ bilježimo istu ideju: „... život nije pjesma, kako ga je on zamišljao. On je najgrublja proza, a tko to ne shvaća, porezat će se do kosti.”, u: Đuro Sudeta, Proza. II. (Tuga, Feljtoni, Humoreske, Intimni Sudeta), Izdanje hrvatskog izdavalačkog bibliografskog zavoda, Zagreb, 1943., 26.

69 Đuro Sudeta, Mor, Školska knjiga, Zagreb, 2005., 24. 
govoj volji - $i$ da bude kako ona želi. Ona je voljela i trpjeti i pregarati nego da to učini., - Čudite se, zar ne, ovom što se dogodilo. Vi to ne razumijete. Ne razumijem ni ja, a ne razumije valjda ni Arno. To razumije samo moj otac. Možda ste me i odsudili; ne bi bilo ni čudo, ali ja sam igrala kod toga toliku ulogu kao vaša ruka kad zaspite pod jorgovanom kad se rascujetava poslije kiše. Ali što to vrijedi govoriti. Danas je to tako i ne može se promijeniti. A kako je do toga došlo, to ne znam ni ja ni oni. S razlikom, što oni znadu što hoće, a ja ne., Šu ostade sama kod vode. Nešto joj nije dalo da ode. Spustila se na prudinu i stala zuriti u dubinu. (...) Misli joj stadoše odlaziti nekuda daleko s kukanjem kukavice i vjetrom koji je dolazio iz šume a kojeg ona nije čula., Šu je šutjela. Osjećala je da Mor govori istinu. Znala je da ih otac otpušta radi nje, ali se činila nevještom. Osjećala je svoju slabost, a ona je i bila možda kriva da je kod sveg toga imala neku čvrstu vjeru da će se sve dobro svršiti. Sve joj se to činilo kao čudan $i$ neugodan san koji će se rasplinuti čim sunce prodre kroz zavjese $i$ unese vedrinu u duše., Osjećam da tako mora biti. Tako i drugi osjećaju. I ne nalaze u tomu ništa neobično, ali, Mor, drugo je logika, a drugo srce. Oni stoje uvijek razdaleko, a kad se ljubi, onda ih nitko više ne može rastaviti. Drugi to nazivaju nedostatkom volje. Možda imaju pravo. Ja ne znam. ${ }^{70}$

Kada se susretnu, Mor i Šu dijele osjećaje i misli, ali ih ne verbaliziraju. Komunikacija se uspostavlja pogledom: Prošli su oboje šuteći, ali su oboje osjećali da su im misli zajedničke. A kad je Mor na rastanku podigao svoje oči do njezinih, zaboravio je na sve što ga je još sinoć tako vrijeđalo i boljelo. One su bile iste, nepomućene i odane - baš kao i lani., Mor se brzo obukao i pokupio mreže, bacio ih preko leđa. Išli su šuteći., - Mor, vi odlazite - prenu se ona kao iz sna. Sjedjeli su na klupi među borovima. Mor se zagledao u zvijezde i uzdahnuo. - Da, Šu. Tako je vaša volja. Ona zadrhta. - Kako to govorite, Mor?... Mor se zagleda dugo u njezine oči. Grudi su mu se zatalasale kao more. Nikad joj oči ne bijahu tako sjajne i velike. - Vi znate istinu bolje od mene. - Onda je bolje: ćutimo. ${ }^{71}$

Šutnja simbolizira njihovu nemoć: - Oprostite mi, Šu. I ja sam samo čovjek, vrlo slab čovjek! - Zar bih ja bila bolja? Mor je opazio da je poslije toga najbolje šutjeti., Mor se okreće i polazi u dolinu $k$ bolesnom ocu - i osjeća da mu je u duši sve ono što je i prije bilo. Zašto joj nije to sve rekao? Zašto je tako slab? ${ }^{72}$

\footnotetext{
$70 \quad$ Isto, $82,31,34,45,51-52$.

71 Isto, 29, 36, 51.

72 Isto, 31, 46.
} 


\subsection{Stari upravitelj i elementi modernističke karakterizacije}

Stari upravitelj također pokazuje obilježja dekadentnog junaka: Upravitelj se vratio iz šume, ostavio je i posao i radnike. Osjeća neki neodređeni nemir., Stari se upravitelj odlučivao da ide u dvor, ali bi uvijek nešto našao za izgovor pred samim sobom. Ustao bi, pošao bi, pa bi se sjetio kakve sitnice. Došlo bi mu da se zamisli, prekrije lice rukama i zaplače., Razmišljao je čitavo prijepodne. Dolažahu mu razne misli na pamet, ali ono pravo - nikako da dođe. Zaokupljen tim mislima - nije ni pošao u dvor da otkaže. ${ }^{73}$

Čak i „kruti“ vlastelin, oslobađajući s vremenom osjećaje, postaje jedan od „likova slutnje“: Možda je vlastelin naslućivao, ali on se nadao da će to vrijeme izmijeniti i izliječiti. Dok zaboravi, dok izumru $i$ oslabe čuvstva. No uza svu nježnost koju je iskazivao prema njoj, osjećao je vlastelin da nešto lebdi između njega $i$ kćerke što ih dijeli $i$ razlučuje. Kao neko zlo čuvstvo i predosjećanje. ${ }^{74}$ Naime, osjećaji koje je pred „logikom života“ zatomio, na površinu izlaze pred „logikom Smrti“: Ali vlastelin kao da je prvi put u životu osjetio da ima dijete. Kao neku slast $i$ strah pred nečim što je moćnije i jače od njegove ljubavi. Osjetio je bliskost smrti i svu veličinu njezinu. A koliko i koliko nježnosti i pažnje mogao je posvetiti i djetetu i sebi već davno prije! Zar mu je to smrt morala otkriti? Zar bi se on prije sjetio da bude prema njoj pažljiv i nježan i da pokori svoje nazore njenim čuvstvima. ${ }^{75}$

Na temelju provedene analize, moguće je zaključiti kako osjećajnost predstavlja svojevrsni „preduvjet“ stvaranja dekadentnoga lika.

\subsection{Prožetosti vanjskoga i unutarnjega}

Unutarnja stanja Sudetinih junaka „zrcale se“ na pojave u „vanjskom svijetu“. Tako je mnogo neodređenosti u tekstu: Netko je prodrmao vratima i otrčao za kuću! Tko je to bio? Kiša se prolijeva preko krova i krošnja. Tanki, tanani plamečci palucaju u zraku, nešto hoda po sobi, dodiruje stvari, miluje obraze i ruke. Ne vidi se, osjeća se., U kolibici je vladala tišina. Neka neodređena tišina., Negdje su stale šumoriti krošnje i gibati se panjevi. Sluša to Mor pa mu se pričinja da nešto stoji iza kuće. Nešto tanko, visoko, prozirno ko sjenka. ${ }^{76}$ Cak i dan odlazi nekuda u daljine. ${ }^{77}$

\footnotetext{
73 Isto, 39, 40.

74 Isto, 64.

75 Isto, 86.

76 Isto, 21, 40, 53.

77 Isto, 19.
} 
Stranice Mora pune su sjenki koje padaju po sobi, dolini, šumi (Po dolini padahu prvi mračci i prozirne sjenke., U šumi se počeo hvatati mračak. ${ }^{78}$ ) ali i po Moru: Mor se prenu i sjenka tuge pade mu preko lica. ${ }^{79}$ Dvorac je, također, samotan, u sjenci: Na suncu drijema vlasteoski dvorac. (...) Oživi li kada, padne li sunce na njega, opet je nešto što ga baca u sjenku. Sad u obliku tišine koja se provlači u sumraku, sad u putovanju vlastelinove kćerke ili tuzi starog vlastelina. U njemu se nešto ugnijezdilo, nešto živi u osobama njegovim, a tko je to - nitko ne zna. Ne zna, ali svak osjeća. Netko kao umor, netko kao strah ili zla predosjećanja. ${ }^{80}$ Bilježi se i motiv tajne: Otajni se zvuk vinu iz duše kao čudo od iskona zapretano. ${ }^{81}$ Vrijedi nadodati kako je treće poglavlje pripovijetke naslovljeno „Otajne slutnje“.

\subsection{Subjekt i pripovjedač}

Nesigurnosti subjekta, poglavito glavnoga lika Mora, prenose se i na pripovjedača: neki su dijelovi teksta napisani u prvom licu, a neki u trećem. Pojava je povezana s tematskom razinom, pa se moramo prisjetiti: „Fantastično je drugo.“82 Mor je „u suživotu“ sa svojim drugim ja. Naratološki gledano, pripovijest je ispripovijedana u prvom i trećem licu „što, dakako, ostavlja značenjske posljedice na ispripovijedano otuđenje glavnog lika čiju metamorfozu u vukodlaka pratimo kroz tekst. Ta pripovjedna putanja bilježi sljedeći niz: od lirskog pripovjedača u 1 . licu, čije su pripovjedno i doživljajno ja $\mathrm{u}$ suzvučju, preko naglašenog reza u kojem je naznačeno njihovo odvajanje, pripovijedanje prelazi u 3. lice koje posreduje monologe četiriju likova da bi naposljetku završilo suzvučnom psihonaracijom. (...) Psihonaracijom ispripovijedana metamorfoza Mora u vukodlaka prikazuje najudaljenije slojeve njegove svijesti koje on sam više kao lik ne može verbalno iskazati: $U$ noć se zavuče u brloge i sluša zvijezde kako tinjaju na pouršini krošnja. Tad mu se pričinja da bi mogao opet govoriti, smijati se i osjećati kao čovjek. A kad ustane i pokuša, bude još žalosniji, još umorniji, jer ne zna! Sve je zaboravio!... Duboka neka tuga zamrači mu i zgusne krv, žile mu se napune otrovom $i$

\footnotetext{
78 Isto, 56, 58.

79 Isto, 20.

80 Isto, 19-20.

81 Isto, 54.

82 Antologija hrvatske fantastične proze i slikarstva (ur. Branimir Donat i Igor Zidić), SNL, Zagreb, 1975., 19.
} 
bijesom. Šulja se tada oko sela i pojata i sasvim - sasvim zaboravlja da je čovjek (M: 128)."83

\section{ZAKLJUČAK}

Impresionistički i općenito lirski elementi samo su jedan od stilskih slojeva u Moru, a pokazuju se na razini odnosa glavnoga lika i prirode, vremena te njegova odnosa s drugim likovima. U skladu s time Mor otvara važna i danas aktualna pitanja identiteta, slobode, ljubavi te funkcije prirode u čovjekovom životu.

\section{ELEMENTS OF IMPRESSIONISM IN MOR BY ĐURO SUDETA}

\section{Summary}

The article interprets the elements of Impressionism in the novella Mor by Đuro Sudeta, relying on the postulates of Impressionistic literature as expounded by Victor Žmegač, on the theories of lyric style by Emil Staiger, and the perception of reality by Ernst Mach. The authors examine the relations of the human body and nature, problems of time, and the Modernist elements of unstable subjectivity in the scope of the main protagonist Mor, the leading female character Šu and her father. The text also shows the closeness of Mor and other heroes of the Modernist period in Croatian literature, such as Leskovar's Marcel Bušinski and Đuro Martić; and Đuka Begović, the hero of the eponymous novel by Ivan Kozarac. racters

Keywords: Sudeta, Mor, Impressionism, subject, nature, cha-

83 Maša Kolanović, Antimodernistički kompleksi Sudetina Mora, u: Komparativna povijest hrvatske književnosti. (Zbornik radova VII. - Hrvatska književnost tridesetih godina dvadesetog stoljeća), Književni krug, Split, 2005., 182, 184. 